\title{
Tying-up syndrome associated with glanders in two mules
}

\author{
Abdullah Araghi-Sooreh', Mehdi Mahmoudi', Tohid Bahmani and Ebrahim Bani Hassan ${ }^{3}$ \\ 1 Department of Veterinary Clinical Sciences, Urmia Branch, Islamic Azad University, Urmia, Iran \\ 2 Faculty of Veterinary Medicine, Urmia Branch, Islamic Azad University, Urmia, Iran \\ 3 Pathology Department and Mackinnon Project, Faculty of Veterinary and Agricultural Sciences, University of Melbourne, Australia
}

\begin{abstract}
Two mules with lameness and tight hind limbs were referred to the veterinary teaching hospital due to losing weight and honeycoloured nasal discharge. Other clinical findings included increased rectal temperature, emaciation and increased heart rate (> $80 \mathrm{bpm})$. Blood samples were taken for haematological and serum biochemical examinations. Creatine kinase (CK) and aspartate transaminase (AST) enzymes showed considerable increases in both cases. The mules were checked using the intradermopalpebral mallein test, and glanders was diagnosed for both cases. To the best of our knowledge, there have been no reports published of tying-up syndrome associated with glanders. Regarding the clinical signs and the results of the increased CK and AST enzymes and myoglobinuria, the most plausible cause of the tying-up syndrome was considered to be rhabdomyolysis. Localisation of the bacteria into the muscles after bacteremia, and subsequent myositis or sedimentation of antigen-antibody complexes in muscles followed by autoimmune reactions may be involved in the clinical signs reported here.
\end{abstract}

Keywords: Tying-up syndrome / rhabdomyolysis / Glanders / mule

\section{Mit Rotz assoziierte Myopathie bei zwei Maultieren}

Zwei Maultiere mit Lahmheit in beiden Hinterbeinen wurden wegen Gewichtsverlust und honigfarbenem Nasenausfluss in die Universitätsklinik überwiesen. Weitere klinische Befunde waren eine erhöhte Rektaltemperatur, Anorexie und eine erhöhte Herzfrequenz (> 80 Schläge/ Minute). Blutproben wurden zur hämatologischen und biochemischen Untersuchung entnommen. Kreatinkinase (CK) und Aspartattransaminase (AST) waren in beiden Fällen deutlich erhöht. Bei beiden Maultieren wurden mittels intradermopalpebralem Malleintest Rotz diagnostiziert. In Anbetracht der klinischen Symptome und der erhöhten CK- und AST-Ergebnisse sowie der Myoglobinämie scheint die wahrscheinlichste Ursache des Kreuzverschlags eine Rhabdomyolyse zu sein. Bakterienwanderung in die Muskulatur nach Bakterämie gefolgt von Myositis oder Absetzung von Antigen-Antikörper-Komplexen in der Muskulatur gefolgt von einer Autoimmunreaktion könnten als Erklärung für die hier berichteten klinischen Symptome in Frage kommen.

Stichwörter: Kreuzverschlag / Rhabdomyolyse / Rotz / Maultier

Citation: Araghi-Sooreh A., Mahmoudi M., Bahmani T., Bani Hassan E. (2015) Tying-up syndrome associated with glanders in two mules. Pferdeheilkunde 31, 608-611

Correspondence: Abdullah Araghi-Sooreh, Associate Professor, Department of Clinical Sciences, Faculty of Veterinary, Urmia Branch 969, Islamic Azad University, Urmia 57135, Iran; E-mail: a.araghi@iaurmia.ac.ir

Ebrahim Bani Hassan, Postdoctoral Researcher, Pathology Department and Mackinnon Project, Faculty of Veterinary and Agricultural Sciences, University of Melbourne, 250 Princes Hwy, Werribee, VIC 3030, Australia; E-mail: bani@unimelb.edu.au

\section{Introduction}

Tying-up syndrome of horses is characterised by muscle stiffness and pain, reluctance to move, sweating and trembling, and is often accompanied by myoglobinaemia and myoglobinuria associated with muscular damage (i.e. rhabdomyolysis) (Oki et al. 2005, Bouwman et al. 2010). Although tyingup is usually associated with metabolic disorders (e.g. exertional rhabdomyolysis or azoturia of horses), other causes, such as unaccustomed exercise (Freestone and Carlson 1991), metabolic disorders (e.g. equine polysaccharide storage myopathy; Valentine 2003), infectious myopathies (Harris 1990, Freestone and Carlson 1991) and immunological myopathies (Reed et al. 2004) have also been reported to contribute to the syndrome.

Glanders is a bacterial disease caused by Burkholderia mallei (Lindler et al. 2004). Horses, mules and donkeys are the species usually affected (Sellon and Long 2014). Humans are susceptible and the infection is usually fatal. Carnivores, including lions, may be afflicted by eating infected meat and infection has also been observed in sheep and goats (Radostits et al. 2007, Kettle and Nicoletti 2014). Horses tend to develop the chronic form, whereas mules and donkeys usually display the acute form, but equids of all ages are susceptible. Invasion occurs mostly through the intestinal wall, followed by septicemia (acute form) or bacteremia (chronic form). Localisation mostly occurs in the lungs, but the skin and nasal mucosa are also common sites. High fever, cough, honeycoloured discharge from nostrils and cutaneous ulcers are common symptoms of the disease in horses (Radostits et al. 2007, Kettle and Nicoletti 2014).

\section{Case report}

Two working mules, each with one hind limb held up (nonweight-bearing lameness), were referred to the Veterinary Teaching Hospital of the Azad University of Urmia (Iran) in January 2012. Their gluteal muscles were hard and painful to the touch and there was a history of inappetence and emaciation within the prior two weeks.

Clinical findings in mule number 1 included: rectal temperature of $39.3^{\circ} \mathrm{C}$, heart rate of $100 \mathrm{bpm}$, severe mucopurulent 
(honey-coloured) nasal discharge, enlarged submandibular lymph nodes, inappetence, discolouration of urine, and the right hind limb was held up constantly. Clinical findings in mule number 2 included: rectal temperature of $39.2{ }^{\circ} \mathrm{C}$, heart rate of $80 \mathrm{bpm}$, enlarged submandibular lymph nodes, inappetence, emaciation and the right hind limb was held up

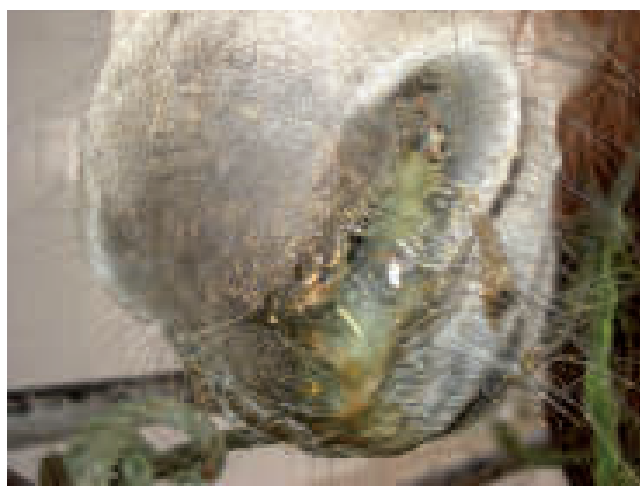

Fig. 1 Honey-colored discharge from nostrils of mule 1. Honigfarbener Nasenausfluss des ersten Maultieres

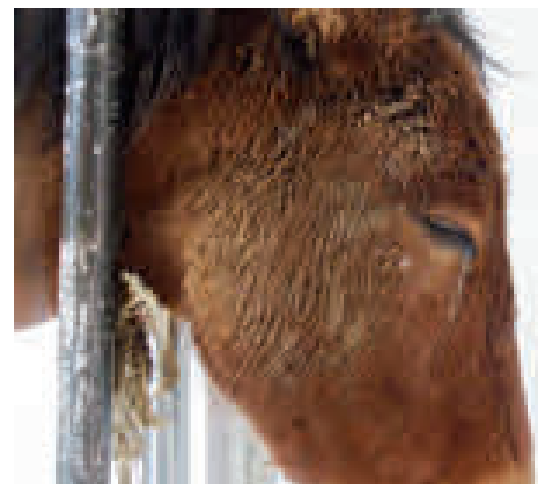

Fig. 2 Right eye of mule 2 after intradermopalpebral mallein test (note to the blepharospasm and purulent discharge).

Rechtes Auge des 2. Maultieres nach intradermopalpebralem Malleintest (man beachte den Blepharospasmus und den purulenten Ausfluss) constantly. After clinical examinations, blood samples were taken for biochemical haematological and serum tests. Due to the lack of normal value for blood parameters and normal vital signs in local working mules recorded, we bled 15 clinically healthy working mules and determined normal haematologic parameters and enzymes activity (Table 1). Normal vital signs are summarised in Table 2 .

Based on the severe honey-coloured nasal discharges in one animal (Figure 1) and considering the sporadic reports of glanders in the region, the mules were tested using intradermopalpebral mallein (Razi Institute, Hesarak, Iran). The test was read $48 \mathrm{~h}$ after malleinisation of the mules and glanders was confirmed in both animals (Hagebock et al. 1993) (Figures 2, 3, 4 and 5; Table 2).

Rhabdomyolysis was confirmed in both mules based on the clinical findings (muscular spasm and pain in both mules), and also myoglobinuria (confirmed after centrifugation of urine and blood) and a marked elevation of serum creatine kinase (CK) and aspartate transaminase (AST) (measured using CK and AST kits supplied by Parsazmoon, Iran; read

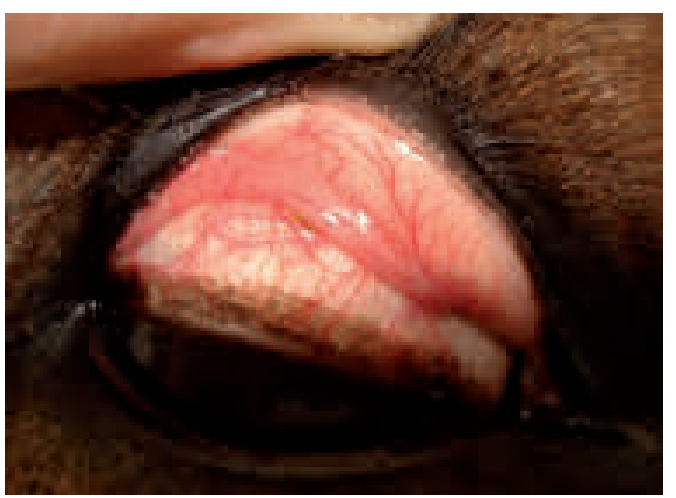

Fig. 3 Severe conjunctivitis in right eye after intradermopalpebral mallein test. | Hochgradige Konjunktivitis im rechten Auge nach intradermopalpebralem Malleintest

\begin{tabular}{|c|c|c|c|c|c|c|c|c|c|c|c|c|c|c|c|c|}
\hline & $\begin{array}{l}\text { RBC } \\
10^{6} \mu \mathrm{l}\end{array}$ & $\begin{array}{l}\text { Fib } \\
\text { g/dl }\end{array}$ & $\begin{array}{l}\text { TPP } \\
\mathrm{g} / \mathrm{dl}\end{array}$ & $\begin{array}{c}\mathrm{MCH} \\
\mathrm{C} \%\end{array}$ & $\begin{array}{c}M C V \\
f L\end{array}$ & $\begin{array}{l}\mathrm{Hb} \\
\mathrm{g} / \mathrm{dl}\end{array}$ & $\begin{array}{c}\text { PCV } \\
\%\end{array}$ & $\begin{array}{c}\text { Bas } \\
\%\end{array}$ & $\begin{array}{c}\text { Eos } \\
\%\end{array}$ & $\begin{array}{c}\text { Mon } \\
\%\end{array}$ & $\begin{array}{l}\text { Lym } \\
\%\end{array}$ & $\begin{array}{c}\text { Band } \\
\%\end{array}$ & $\begin{array}{c}\text { PMN } \\
\%\end{array}$ & $\begin{array}{l}\text { WBC } \\
10^{3} \mu \mathrm{l}\end{array}$ & $\begin{array}{l}\text { CK } \\
U / L\end{array}$ & $\begin{array}{l}\text { AST } \\
U / L\end{array}$ \\
\hline Normal & $\begin{array}{c}8.5 \\
\pm 0.5\end{array}$ & $\begin{array}{c}0.44 \\
\pm 0.15\end{array}$ & $\begin{array}{c}8.08 \\
\pm 0.41\end{array}$ & $\begin{array}{c}32.6 \\
\pm 1.25\end{array}$ & $\begin{array}{c}44.8 \\
\pm 0.75\end{array}$ & $\begin{array}{r}12.5 \\
\pm 1.06\end{array}$ & $\begin{array}{c}38.4 \\
\pm 5.52\end{array}$ & 0 & $\begin{array}{c}4 \\
\pm 2.5\end{array}$ & $\begin{array}{c}4.4 \\
\pm 1.95\end{array}$ & $\begin{array}{c}42 \\
\pm 10\end{array}$ & $\begin{array}{c}4 \\
\pm 3.75\end{array}$ & $\begin{array}{l}45.4 \\
\pm 6.9\end{array}$ & $\begin{array}{l}11.4 \\
\pm 2.2\end{array}$ & $\begin{array}{l}295.56 \\
\pm 38.76\end{array}$ & $\begin{array}{l}409.95 \\
\pm 44.82\end{array}$ \\
\hline Mule 1 & 8.8 & 0.9 & 10.7 & 33 & 44 & 13 & 39 & 0 & 0 & 15 & 9 & 26 & 50 & 17 & 100500 & 21200 \\
\hline Mule 2 & 6.08 & 0.6 & 10.4 & 31 & 46 & 19 & 28 & 0 & 0 & 3 & 5 & 32 & 60 & 16.5 & 80170 & 19500 \\
\hline \multicolumn{17}{|l|}{ Tab. 2} \\
\hline & & \multicolumn{5}{|c|}{ Heart Rate (bpm) } & \multicolumn{5}{|c|}{ Respiratory Rate (bpm) } & \multicolumn{5}{|c|}{ Temperature $\left({ }^{\circ} \mathrm{C}\right)$} \\
\hline Normal & & \multicolumn{5}{|c|}{$35.8 \pm 3.7$} & \multicolumn{5}{|c|}{$16.1 \pm 2.8$} & \multicolumn{5}{|c|}{$37.47 \pm 0.41$} \\
\hline Mule 1 & & \multicolumn{5}{|c|}{100} & \multicolumn{5}{|c|}{27} & \multicolumn{5}{|c|}{39.3} \\
\hline Mule 2 & & \multicolumn{5}{|c|}{80} & \multicolumn{5}{|c|}{24} & \multicolumn{5}{|c|}{39.2} \\
\hline
\end{tabular}

Tab. 3 Interpretation of intradermopalpebral mullein test in equids (Goodall 1915)

\begin{tabular}{lcccc}
\hline Interpretation & Purulent discharge from eye & Complete closing of eye & Conjunctival hyperemia & Eyelid swelling \\
\hline Negative & - & - & - & - \\
Doubtful & $-/+$ & - & + & + \\
Positive $(++)$ & + & - & + \\
Positive $(+++)$ & + & + & + \\
\hline
\end{tabular}


using a Hitachi 917 autoanalyser, Japan). The normal CK and AST activity values (mean \pm SD) are $295.56 \pm 38.76$ and $409.95 \pm 44.82 \mathrm{U} / \mathrm{L}$, respectively; however, in the affected mules, No. 1 and 2, the values increased to 100500 and $80170 \mathrm{U} / \mathrm{L}(\mathrm{CK})$ and 21200 and $19500 \mathrm{U} / \mathrm{L}$ (AST), respectively. Case histories revealed that signs consistent with rhabdomyolysis had started about a week to ten days after the onset of the early respiratory signs detected by the carer (Table 1).

Mule number 1 died four days after the mallein test, possibly due to septicemic shock and general malaise associated with inappetence. Mule number 2 was euthanized based on zoonotic risk and welfare grounds, and both animals were buried deeply (in a hole over $3 \mathrm{~m}$ in depth), in accordance with the Iranian national glanders eradication programme). The owners and animal attendants were warned about the zoonotic nature of the condition and the premises were carefully disinfected. The disease incidence was reported to the responsible veterinary body of the province.

\section{Discussion}

The etiology of most cases of acute rhabdomyolysis is unknown. However, suggested causes include hypothyroidism, sodium or potassium deficiency, viral infection, high carbohydrate diets and abnormalities in metabolic function. The most common cause is performing exercise of unaccustomed intensity or duration, which can result in metabolic exhaustion and hyperthermia. However, the disease is not always associated with severe exertion or hyperthermia, and can also occur with little exercise, such as slow draught work or even putting the animals out to pasture after stabling (Radostits et al. 2007). Rhabdomyolysis also occurs in horses with strangles caused by Streptococcus equi infection (Reed et al. 2004).

The syndrome occurs due to dysfunction, injury and/or death of myocytes with the subsequent release of cellular constituents, including the enzymes CK and AST and myoglobin (Sacheck and Blumberg 2001, Radostits et al. 2007). The exact pathogenesis of myocyte death is uncertain in the exertional type of the disease, but the accumulation of lactic acid and consequent tissue injury suggested previously has been rejected (Valberg et al. 1993). Proposed alternative mechanisms include oxidant injury to cells as a result of increased oxidant formation during exercise or inadequate antioxidant activity (Sacheck and Blumberg 2001). Apart from vitamin E and/or selenium deficiency, which are rare in horses, there is no indication that oxidant injury is a common cause of rhabdomyolysis in horses (Chioradia et al. 1998). Cell death is probably linked to abnormal accumulation of calcium in the intracellular fluids, secondary to deranged energy and/or membrane function (Hinchcliff and Kaneps 2014).

Since this is the first report published of rhabdomyolysis associated with glanders, the pathogenesis of muscular injury within was not specific to us. Muscular injury may be caused by the localisation of bacteria from the blood into the muscles and subsequent bacterial activity, circulating toxins or sedimentation of antigen-antibody complexes in muscles resulting in autoimmune reactions. Rhabdomyolysis associated with inappetence-induced hypokalemia or a combination of meta- bolic and immunologic processes are also possible pathways. However, more studies are required to determine the mechanisms involved.

Two forms of immune-mediated myositis have been described in horses associated with Strep. equi infection: immunoglobulin (lg) G-and lg A-mediated. Both are less common than purpura haemorrhagica, another feature of Strep. equi infection, characterised by general immune-mediated vasculitis that occurs as a result of type 3 (Arthus) reaction (Sellon and Long 2014). lgG-mediated myositis in horses is characterised by a rapid onset of muscle wasting. The lg-A-mediated form of post streptococcal myositis of horses is known as Henoch-Schönlein purpura and is a significantly more malignant form of myositis (Reed et al. 2004). Muscle pain or myalgia is a common symptom in the acute phase of equine influenza and equine herpes virus-1 infections (Harris 1990, Freestone and Carlson 1991).

Rhabdomyolysis has been commonly reported in horses, but, according to an extensive literature search, it appears that, irrespective of the etiology, this is the first report of rhabdomyolysis in mules. It has been claimed that mules are more patient, sure-footed, hardy and long-lived than horses (Jackson 2004). Mules are more resistant to pain (especially musculoskeletal pain) and work-related fatigue disappears faster in mules than in horses, therefore, they are less likely to be exerted excessively (Matthews et al. 1997). Probably because of these differences, mules are apparently more resistant to rhabdomyolysis.

Cremation and burying the infected cadavers, in-contact fomites and disposables, along with careful disinfection of conveyances, equipment and premises are recommended by the OIE (World Organisation for Animal Health) protocols (OIE 2013). Additionally, as a reportable disease in almost every country in the world, the responsible bodies for zoonoses and disease control centres should be actively informed of the disease occurrence.

Haematology was indicative of lymphopaenia and an obvious shift to the left in both animals, and severe monocytosis in mule number 1 was consistent with the infectious nature of the syndrome. The mildly-increased total serum protein can be ascribed to myoglobinaemia and increased fibrinogen.

Our study was subject to some limitations. We used the mallein test (by nature, an allergenic reaction to a bacterially purified protein derivative) to confirm the diagnosis of glanders. In addition, due to disease control concerns, we did not attempt to isolate the agent. It should be considered that in the European Union and particularly in Germany, the mallein test has been replaced by more specific methods, such as PCR and serology, and particularly the complement fixation test (CFT) for international trade (Neubaver et al. 2005).

Several other serological tests and diagnostic techniques are now available for glanders diagnosis, including indirect haemagglutination, enzyme-linked immunosorbent assay (ELISA), counter immuno-electrophoresis, Rose-Bengal staining, and competitive ELISA (OIE 2013). The CFT as the recommended test is also subject to some limitations, such as the possibility of false-positive results. A Western immunoblot technique has 
recently been proposed for resolving the false-positives found in the CFT for use in areas with low glanders prevalence (Elschner et al. 2011).

The false-negative and -positive results can be associated with interspecies differences (as most of such tests are designed for horses) or are thought to originate - at least in part - from the use of crude cell-antigen preparations in addition to crossreactions with other bacteria (Sprague et al. 2009). Where possible, using a selective combination of methods as alternatives for negative tests is advisable. Culture, immunohistochemistry and inoculation in guinea pigs should be considered as the last option if the associated risks, expenses or animal welfare issues, respectively, can be justified.

In conclusion, considering the clinical signs and paraclinical features of the condition reported here, glanders disease should be suspected in endemic areas if equids display tyingup syndrome, myoglobinuria, increased muscular enzymes and non-typical respiratory signs.

\section{Acknowledgements}

The authors are grateful to Dr. Christina Marth and Dr. Natali Krekeler for translating the abstract into German. We also wish to thank Ms. Sharni Brazier who assisted in the proofreading of the manuscript.

\section{References}

Bouwman F. G., van Ginneken M. M., van der Kolk J. H., van Breda E., Mariman E. C. (2010) Novel markers for tying-up in horses by proteomics analysis of equine muscle biopsies. Comp. Biochem. Physiol. Part D Genomics Proteomics 5, 178-83

Chiaradia E., Avellini L., Rueca F., Spaterna A., Porciello F., Antonioni M. T., Gaiti A. (1998) Physical exercise, oxidative stress and muscle damage in racehorses. Physical exercise, oxidative stress and muscle damage in racehorsesComp. Biochem. Physiol. Part B. $119,833-836$

Elschner M. C., Scholz H. C., Melzer F. (2011) Use of a western blot technique for the serodiagnosis of glanders. BMC Vet. Res 7, 4
Freestone J. F., Carlson G. R. (1991) Muscle disorders in the horse: A retrospective study. Equine Vet. J. 23, 86-90

Goodall C. (1915) The intrapalpebral mallein test. J. Comp. Pathol. Therapeutics 28, 281-297

Hagebock J. M., Schlater L. K., Frerichs W. M., Olson D. P. (1993) Serological responses to the mallein test for glanders in solipeds. J. Vet. Diagn. Invest. 5, 97-9

Harris P. A. (1990) An outbreak of the equine rhabdomyolysis syndrome in a racing yard. Vet. Rec. 127, 468-470

Hinchcliff K. W., Kaneps A. J., Geor R. J. (2014) Muscle disorders of equine athletes. In: Equine Sports Medicine and surgery. 2nd edition, Saunders Elsevier, Edinburgh. 109-137

Jackson L. A. (2004) The mule men: a history of stock packing in the Sierra Nevada. Mountain Press Publishing Co, Missoula, MT.5

Lindler L. E., Lebeda F. J., Korch G. (2004) Glanders: new insights into an old disease. In: Biological weapons defense: infectious diseases and counterbioterrorism. Humana Press, Totowa, NJ. 209-237

Matthews N., Taylor T., Hartsfield S. (1997) Anaesthesia of donkeys and mules. EquineVet. Educ. 9, 198-202

Neubaver H., Sprague L. D., Zacharia R. (2005) Serodiagnosis of Burkholderia mallei infections in horses: state-of-the-art and perspectives. J. Vet. Med. B Infect. Dis. Vet. Public Health 52, 201-205

OIE (2013) Manual of diagnostic tests and vaccines for terrestrial animals. Chapter 2.5.11: Glanders, OIE, Paris

Oki H., Miyake T., Hasegawal T., Sasaki Y. (2005) Estimation of heritability for Tying-up syndrome in the Thoroughbred racehorse by Gibbs sampling. J. Anim. Breed. Genet. 122, 289-293

Reed S. M., Bayly W. M., Sellon D. B. (2004) Disorders of Specific Body System, In: Equine Internal Medicine. 2nd edition. Saunders, St. Louis, MO. 500-504

Radostits O. M., Gay C. C., Constable P. D. (2007) Veterinary Medicine. A textbook of the diseases of cattle, horses, sheep, pigs, and goats. 10th edition, Saunders Elsevier, New York. 1083-1085, 1683-1684

Sellon D. C., Long M. T. (2014) Glanders. In: Equine Infectious Diseases. 2nd edition. Saunders Elsevier, St. Louis, MO, 333-336

Sacheck J. M., Blumberg J. B. (2001) Role of vitamin E and oxidative stress in exercise. Nutrition 17, 809-14

Sprague L. D, Zachariah R., Neubaver H. (2009) Prevalence dependent use of serological tests for diagnosing glanders in horses. BMC Vet. Res. 5, 32

Valberg S., Häggendal J., Lindholm A. (1993) Blood chemistry and skeletal muscle metabolic responses to exercise in horses with recurrent exertional rhabdomyolysis. Equine Vet. J. 25,17-22

Valentine B. A. (2003) Equine polysaccharide storage myopathy. Equine Vet. Educ. 15, 254-262 